\title{
Application of Electrical Resistivity for Evaluation of Groundwater Occurrence Within Adankolo Campus and Environs, Lokoja North Central, Nigeria
}

\author{
Mu'awiya B. Aminu, Changde A. Nanfa, Jubril I. Hassan, Isah Yahuza, \\ Simon D. Christopher, and Godwin O. Aigbadon
}

\section{ABSTRACT}

This study addresses the problem of determining water bearing zones in Adankolo campus of Federal University Lokoja and environs. An inquiry into groundwater was done using electrical resistivity to measure the resistivity variations of the subsurface formations with depth. A vertical electrical sounding VES that is compatible to the Schlumberger configuration were allocated to the mapped areas. The research aims at finalizing investigation on groundwater occurrence using electrical resistivity method, which has the aim of providing a geological map of the study area that can carry-out electrical resistivity sounding in some selected places within the study area to analyse the groundwater condition from geo-electrical and hydrogeological characteristics of the aquifer(s) that are present within the study area.

Keywords: Aquifer, Electrical resistivity, Groundwater.

\section{INTRODUCTION}

Access to safe water is key to health improvement and alleviate poverty [1]. Irrigation, industrialization, and rising population has made clear the obstacles a supply quality water face. As a result, surface water cannot be sufficient for
Published Online: January 22, 2022

ISSN: $2684-446 \mathrm{X}$

DOI :10.24018/ejgeo.2022.3.1.235

\section{B. Aminu*}

Department of Geology, Faculty of Sciences, Federal University Lokoja, Kogi State, Nigeria.

(e-mail:

muawiya.babaaminu@fulokoja.edu.ng) C. A. Nanfa

Department of Geology, Faculty of Sciences, Federal University Lokoja,

Kogi State, Nigeria.

(e-mail:

Nanfa.changde@fulokoja.edu.ng)

J. I. Hassan

Ahmadu Bello University, Zaria.

Department of Geology, Ahmadu Bello University Zaria Kaduna, Nigeria.

(e-mail: jihassan@abu.edu.ng)

I. Yahuza

MSc. Economic Geology/Mineral Exploration, Abubakar Tafawa Balewa University Bauchi, Nigeria.

B. Tech Applied Geology, Abubakar Tafawa Balewa University Bauchi, Nigeria.

Lectures, Air Force Institute of Technology, PMB 2104, Kaduna, Nigeria.

Member, Nigerian Mining and Geosciences Society (MNMGS)

(e-mail: i.yahuza@afit.edu.ng)

S. D. Christopher

Department of Geology, Faculty of Sciences, Federal University Lokoja, Kogi State, Nigeria.

(e-mail:

simon.christopher@fulokoja.edu.ng)

G. O. Aigbadon

Department of Geology, Faculty of Sciences, Federal University Lokoja,

Kogi State, Nigeria.

(e-mail:

godwin.aigbadon@fulokoja.edu.ng)

*Corresponding Author 
geological formation. Groundwater is easier to use when detected in sedimentary terrains. It is difficult to locate when it is within the basement complex, especially in areas underlined by crystalline rocks [2]. Data is crucial in the subject of groundwater and rudimentary if it is to be developed [3]. The rapid advances in computer software and other numerical modelling procedures have caused a manifold increase in deploying geophysical techniques to explore groundwater and assess water quality. Geo-physical surveys are extremely popular thanks to its simplicity. Discovering the effects on the surface that caused the flow of electric currents in the world is the primary objective of the electrical geophysical survey method. These techniques are deployed in various geophysical investigations such as archaeological investigation, engineering studies, mineral exploration, geothermal exploration, permafrost mapping and geological mapping.

Electrical resistivity is a geophysical survey technique that is utilized in detecting feasible pore water for progressive facilitation [4]. Compared to alternative geophysical survey methods, this has less possibility of destructive repercussions on the environment, costs less, it is rapid, faster survey time, and very low vagueness of results. The conventional Schlumberger array is a prominent constellation within the vertical electrical sounding (VES). It contains electrodes spread on either side of the array spread to achieve a symmetrical layout [5], [6]. Available information is mainly regulated by lithological conditions of the aquifer; electrical resistivity is mostly deployed for hydrogeology studies. The technique is equally functional in the correlation of lithological facies between wells [7].

The Adankolo area where Federal University is located faces problems of defunct wells and boreholes that are results of weak understanding of the hydro geophysical characteristics of the basement groundwater [8].

It is essential to establish background data for the future aquifer development to decrease instances of borehole failures but the same can be said about conducting a systematic hydro geophysical investigation of the metropolis.

\section{PHYSICAL-GEOGRAPHICAL AND GEOLOGICAL CHARACTERISTICS}

\section{A. Location and Accessibility}

Federal University Lokoja and its environs are the focal point of this study, which comprises of Ganaja junction up to Government Residential Area, (GRA) and cinema junction. The study includes both minor and major roads, which can be accessed easily by heavy tankers, bus, Lorries, cars and motorcycles. The study area lies between latitudes N07 $51^{\prime} 50.5^{\prime \prime}$ and longitude E06 $41^{\prime} 01.1^{\prime \prime}$. This area is vastly connected and reachable via federal and state main roads. It is also located close at the point of intersection of the River Niger and Benue. It is sandwiched between a water body and a hill i.e., River Niger and Mount Patti respectively, which had linearly contoured the settlement and has a customizing effect on the climate.

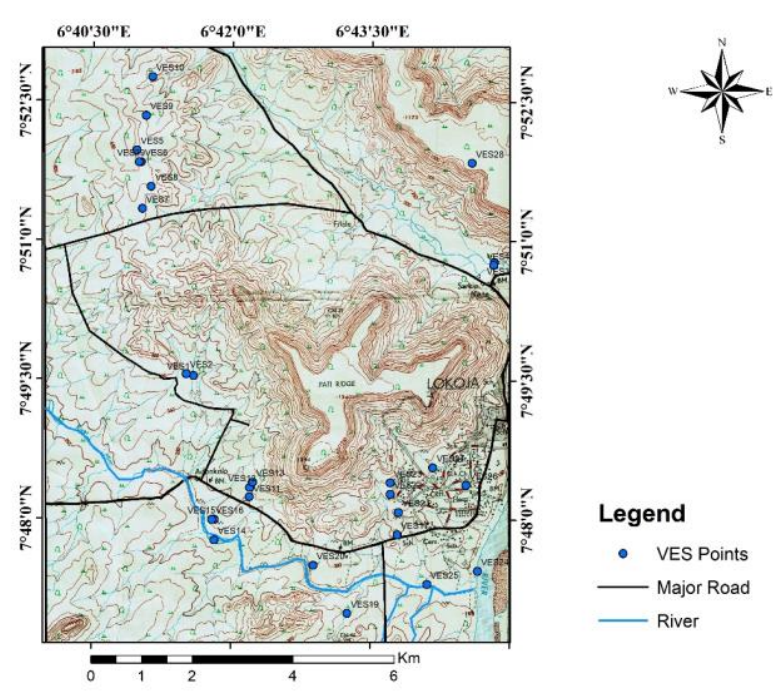

Fig. 1. Study area showing the various VES locations.

\section{B. Topography}

Lokoja sub-basin, part of Mid Niger basin is characterized by undulating topography with limited flat terrain [9], [11]. This is typical of Mount Patti and Agbaja plateau which are the two main highlands in the area. Mount Patti is a linear NW - SE ridge parallel to Agbaja Plateau with an altitude of about $442.25 \mathrm{~m}$ both following the basin trend and perpendicular to the main axis of the Benue trough [9], [11]. These highlands are capped by indurated and ferruginous sandstones. They also extend across the Niger River towards Bassa and terminating around Gboloko Monzum area. The eastern, southwestern and southeastern parts of Lokoja area have altitudes ranging between 50 metres and 90 metres and are underlain by Basement rocks.

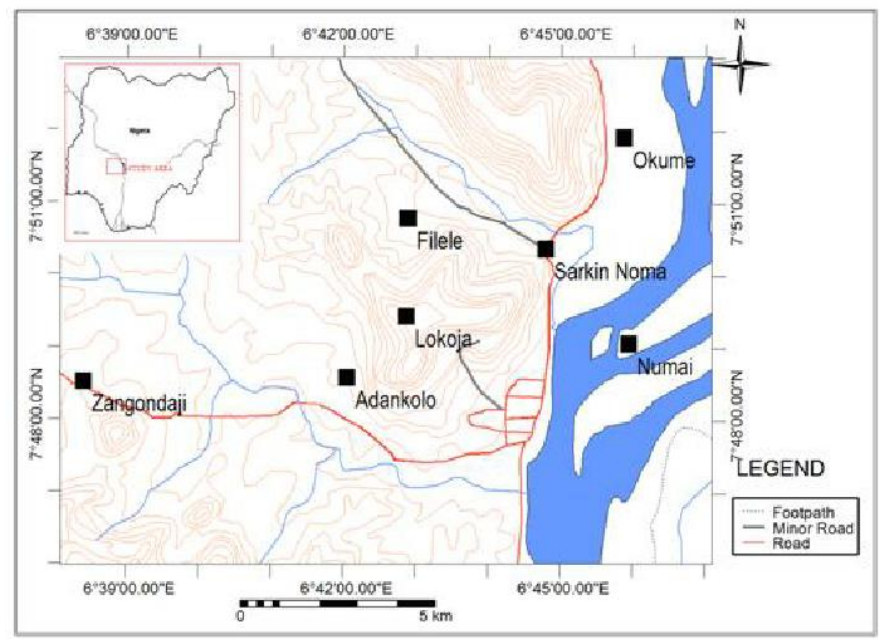

Fig. 2. Topographic map of Adankolo and environs (Modified after [10] [9]).

\section{Climate}

The southern Bida Basin lies within the tropical climate marked by wet and dry seasons. The dry season sets in during November and lasts until March. It is followed by a wet or rainy season from April to October with maximal rainfall in June and September. The annual amount of rainfall within the area is between 1200 and $1500 \mathrm{~mm}$. Relative humidity is about 90 percent in the morning and drops to about 80 percent in the dry season. The annual temperature ranges between $16^{\circ} \mathrm{C}$ and $37^{\circ} \mathrm{C}$. During the 
rainy season, the area is under the influence of moistureladen southwest trade winds which give way to the dry and sometimes dusty northeast winds (Harmattan) during the dry season [9].

\section{Vegetation}

The southern Bida Basin lies within the Guinea Savannah vegetation belt characterized by trees and grasses with numerous trees in sparsely settled area and heavy forests along the river valleys. The main vegetation type in Lokoja is guinea or parkland savannah with tall grasses and trees. These are green in raining season with fresh leaves and tall grasses, but the land is open during dry season, showing charred trees and the remains of burnt grasses, [9].

\section{E. Relief and Drainage}

The southern Bida Basin is characterized by undulating terrain with limited flat terrain. This is typical of Patti hill and Agbaja Plateau which are the two main hills in Lokoja area. Patti hill attains an elevation of $1500 \mathrm{~m}$. Falconer [9] described Mount Patti as linear NW-SE ridge parallel to Agbaja Plateau with an altitude of about $1450 \mathrm{~m}$ both following the basin trend perpendicular to the main axis of the Benue Trough These high lands are capped by indurated and ferruginous sandstone. This hill also extends across the Niger River toward Bassa and terminating around GbolokoMonzum area. The geomorphological features in the southern Bida Basin consist of River Niger, its flood plain and tributaries characterized by belt of mesas and plains. The area is being drained by Rivers Niger and Benue. Other minor rivers and streams like River Mimi flowing southward into River Niger exactly at the confluence. Patti stream which is more or less a flow of connate water gushing out of sediment and flowing into River Niger in southeastern direction. River Abaji also flows in southeastern direction into River Niger. Most of these streams are intermittent and thus dry off at the peak of dry season. Generally, the drainage pattern is simply dendritic where many tributaries join the major river [9].

\section{MATERIALS AND METHODS}

The materials and methods used to do the survey are discussed in this section.

\section{A. Geological Mapping}

It started with a reconnaissance of the Adankolo campus of the Federal University Lokoja and Environs. Data was collected in form of rock samples, photographs, measurements, and notes after field mapping was executed. This was helpful in obtaining the basic knowledge about the prevailing field conditions not only through the direct measurements but also by the collecting and analyzing rock, mineral and sediment samples, and measurements of the geometric aspects. The following equipment were used to do a geological mapping of the area: hammer, Global Positioning System (GPS), compass, chisel, hand magnifiers and sample bags.

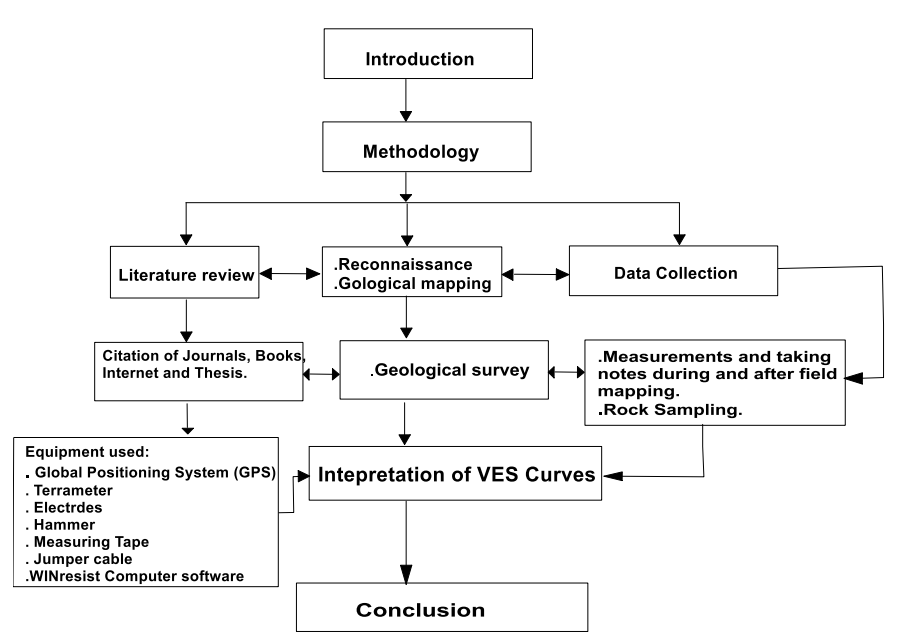

Fig. 3. Workflow chart adopted for this research.

Vertical Electrical Sounding (VES) was used to obtain the subsurface measurements of the area using Schlumberger array which carried out at nine (9) VES locations across the mapped area. The DDR3 tool used is the Geo-sensor terrameter, which is the modern variation. Resistance readings at each VES point were promptly displayed on the digital screen and noted in the provided book for the survey. The graphs were plotted, and different layers and the depth of each layer delineated using the WINresist computer software.

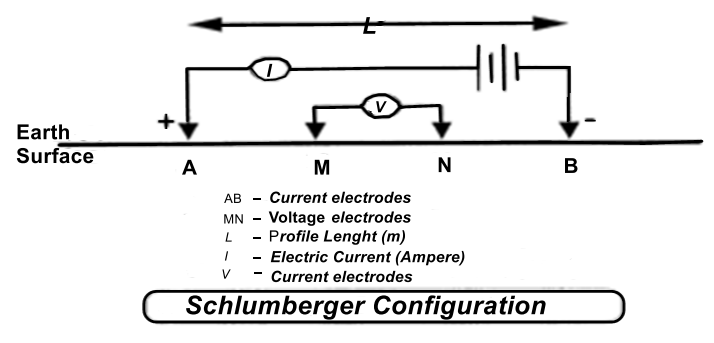

Fig. 4. Schlumberger array of vertical electrical sounding.

$$
K=\pi\left[\frac{\left(\frac{A B}{2}\right)^{2}-\left(\frac{M}{N}\right)^{2}}{M N}\right]
$$

$$
\rho_{a}=G R
$$

$\rho_{a}=\pi\left[\frac{\left(\frac{A B}{2}\right)^{2}-\left(\frac{M N}{2}\right)^{2}}{M N}\right] R$

where $\rho_{a}$ is Apparent resistivity, " $G$ " is the Geometric factor, and " $R$ " is the Ground resistance. The apparent resistivity was used for the partial curve matching.

The tools deployed for Geophysical Survey included:

\section{1) Terrameter}

The Terrameter is used in measuring volt, current, and soil resistivity and also helps send current through a pair of 
electrodes, and evaluates the potential generated across another pair of electrode cables the Terrameter is connected to. The Type of equipment used in carrying out this survey is the DDR 3 sensor terrameter. The Terrameter displayed the resistance as the potential difference to the current ratio. A geometric factor was set in meters (m) and was computed as a function of the electrode spacing. The received readings of the resistance by the Terrameter were multiplied by this factor to provide a clear value of resistivity. The electrode spacing is progressively raised, fixing the electrode array at its center point.

\section{2) Cables}

Insulated, light weight and high strength wires.

\section{3) Electrodes}

These are pieces of stainless steel rod that are buried deep into the ground to transmit current to the sub-surface, or used in sending current to earth crust.

\section{4) Hammer}

It is used for tapping electrode to be firmly pegged in the ground.

\section{5) Jumper Cable}

The cable reel is connected to the electrode using this and then to the terrameter.

\section{6) Measuring tapes}

These are tapes spread over both sides of the area that was surveyed; it is used to point out the place where electrodes are to be hammered.

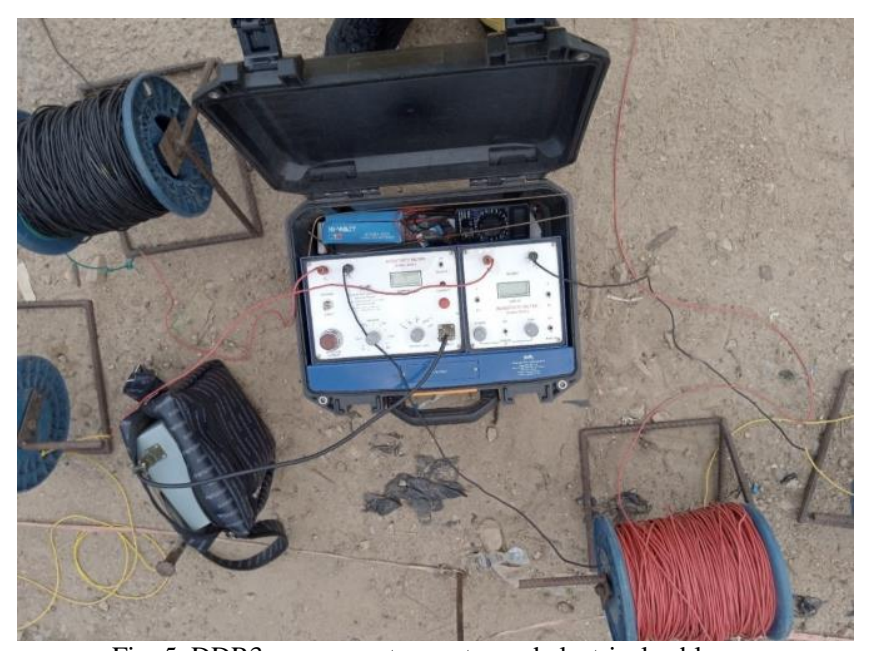

Fig. 5. DDR3 geosensor terameter and electrical cables.

\section{B. Geology of the Study Area}

Geology of the Adankolo Campus of Federal University Lokoja and its environs is similar to the geology of Lokoja which is dominantly braced by the Precambrian Basement Complex. However, part of the area is trussed by Cretaceous sediments which uncomformably overlapped the Basement Complex. Migmatite contain about half of the area outcropping at the southwest, west, northwest and central parts of the area. The South and the southeast parts of the area are braced by not differentiated older granite, mainly porphyroblastic granite, granite gneiss with porphyroblastic gneiss and fines grained biotite granite.
The main major rocks types that was discovered during the mapping of the area are migmatites, gneiss and biotite which is predominantly at the Federal University campus, Adankolo, and Ganaja area, while there are slight events of rock types like pegmatites, and quartzo-felpathic veins. Lokoja formation is found mostly on the Patti hill, around the GRA area.

\section{Basement Complex}

The basement complex is one of the three important lithopetrological components that make up the geology of Nigeria (Fig. 3). The Nigerian basement complex forms a part of the Pan-African mobile belt and lies inbetween the West African and Congo Cratons and south of the Tuareg Shield. It is intercalated by the Mesozoic calc-alkaline ring complexes (Younger Granites) of the Jos Plateau and is unconformably overlain by Cretaceous and younger sediment. The Nigerian basement was counterfeited by the $600 \mathrm{Ma}$ Pan-African orogeny and it occupies the reactivated region which resulted from plate collision between the passive continental margin of the West African craton and the active Pharusian continental margin [12] The basement rocks are believed to be the results of at least four major orogenic cycles of deformation, metamorphism and remobilization corresponding to the Liberian $(2,700 \mathrm{Ma})$, the Eburnean (2,000 Ma), the Kibaran (1,100 Ma), and the Pan-African cycles (600 Ma). The first three cycles were identified by intense deformation and isoclinal folding accompanied by regional metamorphism, which was further followed by large migmatization. The Pan-African deformation was followed by a regional metamorphism, migmatization and extensive granitization and gneissification which produced syntectonic granites and homogeneous gneisses [13] Late tectonic emplacement of granites and granodiorites and linked contact metamorphism accompanied the end stages of this final deformation. The end of the orogeny was marked by faulting and fracturing [14]. Surrounded the basement complex of Nigeria four major petro-lithological units which are distinguishable are as follows:

1. The Migmatite - Gneiss Complex (MGC).

2. The Schist Belt (Metasedimentary and Metavolcanic rocks).

3. The Older Granites (Pan African granitoids).

4. 4.The Undeformed Acid and Basic Dykes.

\section{The Migmatite - Gneiss Complex (MGC)}

The Migmatite - Gneiss Complex is bascally considered as the basement complex sensu stricto [15];[16] and it is the most widespread of the component units in the Nigerian basement. It has a heterogeneous assemblage comprising migmatites, orthogneises, paragneisses, and a series of basic and ultrabasic metamorphosed rocks. Petrographic evidence indicates that the Pan-African reworking led to recrystallization of many of the constituent minerals of the Migmatite - Gneiss Complex by partial melting with most of the rock types displaying medium to upper amphibolite facies metamorphism. The Migmatite - Gneiss Complex has ages differ from Pan-African to Eburnean.

The Migmatitite-Gneiss Complex also named by some workers as the "migmatite-gneiss-quartzite complex" forms up about $60 \%$ of the surface area of the Nigerian basements 
[17]. These rocks record three major geological events[18]; the earliest, at 2,500 Ma, involved instation of crust forming processes (e.g. the banded Ibadan grey gneiss of mantle origin) and of crustal growth by sedimentation and orogeny; next came the Eburnean, 2,000 $\pm 200 \mathrm{Ma}$, marked by the Ibadan type granite gneisses; this was followed by ages in the range from 900 to $450 \mathrm{Ma}$ which represent the imprint of the Pan-African event which not only structurally overprinted and re-set many geochronological clocks in the older rocks, but also gave rise to granite gneisses, migmatites and other similar lithological units. The close analogy in time with the development of the Birrimian of the West African Craton is striking. However, although gold, manganese and iron mineral deposits are associated with Birrimian rocks, the same age rocks in Nigeria are very sparsely, if at all, mineralized. The extent of Eburnean and older rocks in Nigeria is not known. Definite geochemical evidence for the presence of these rocks being in the area south of latitude $9^{\circ} \mathrm{N}$ [18]. Lithologically homogeneous rocks in other parts of Nigeria, especially in the northeast and southeast, have set only Pan-African ages [19].

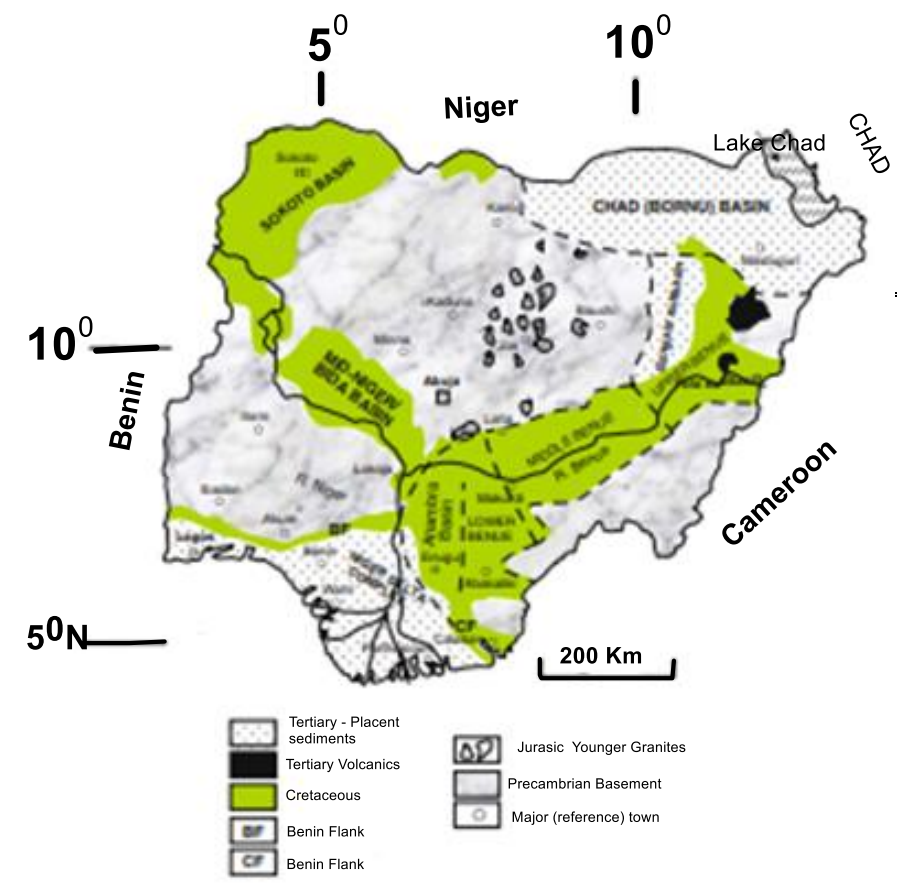

Fig. 6. Geological map of Nigeria showing the major geological component, (after [20]).

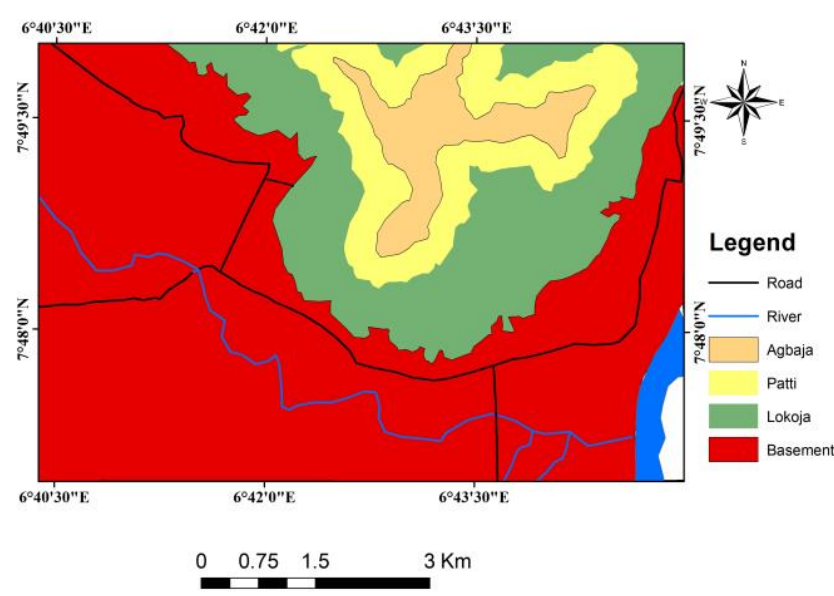

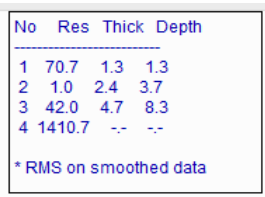

The Winresist Software was used to produce the results of the Vertical Electrical Sounding (VES), which are presented in tables and graphs.

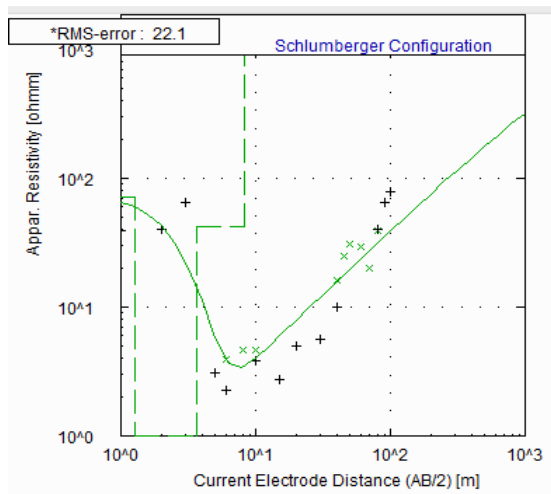

Fig. 8. VES 1curve.

TABLE I: RESISTIVITY RANGES AND THE THICKNESS OF THE LAYER OF THE SUBSURFACE LITHOLOGIC UNITS

\begin{tabular}{|c|c|c|c|c|}
\hline $\begin{array}{l}\text { No. Of } \\
\text { layers }\end{array}$ & $\begin{array}{c}\text { Resistivity } \\
(\Omega \mathrm{m})\end{array}$ & $\begin{array}{l}\text { Depth } \\
\text { (m) }\end{array}$ & Possible lithology & Remark \\
\hline 1. & 70.7 & 1.3 & $\begin{array}{c}\text { Top soil and/or } \\
\text { lateritic overburden }\end{array}$ & Vadose zone \\
\hline 2. & 1.0 & 3.7 & $\begin{array}{l}\text { Weathered } \\
\text { basement }\end{array}$ & $\begin{array}{l}\text { Semi permeable } \\
\text { layer }\end{array}$ \\
\hline 3. & 42.0 & 8.3 & $\begin{array}{c}\text { Fractured /fairly } \\
\text { weathered } \\
\text { basement }\end{array}$ & Fracture zone \\
\hline 4. & 1410.7 & & $\begin{array}{l}\text { Weathered-fresh } \\
\text { basement }\end{array}$ & Confining zone \\
\hline
\end{tabular}

Results of VES 1is presented in Fig. 1 and Table I. The topsoil layer, which is composed of loosely nonamalgamated sandy soil, has a thickness value of $1.3 \mathrm{~m}$ and resistivity value of $70.7 \Omega m$, as indicated by the result. What came after was a thick and resisting weathered layer at values of $3.7 \mathrm{~m}$ and $1.0 \Omega \mathrm{m}$. This is regarded as sandyclayed soil. This is followed by the aquifer layer that has a thickness and resistivity values of $8.3 \mathrm{~m}$ and $42.0 \Omega \mathrm{m}$. This layer is regarded coarse sand and held the pore water. A layer of fine-medium sand came next, and it has resistivity value of $1410.7 \Omega \mathrm{m}$ and an undefined thickness. Curve type is $\mathrm{H}$.
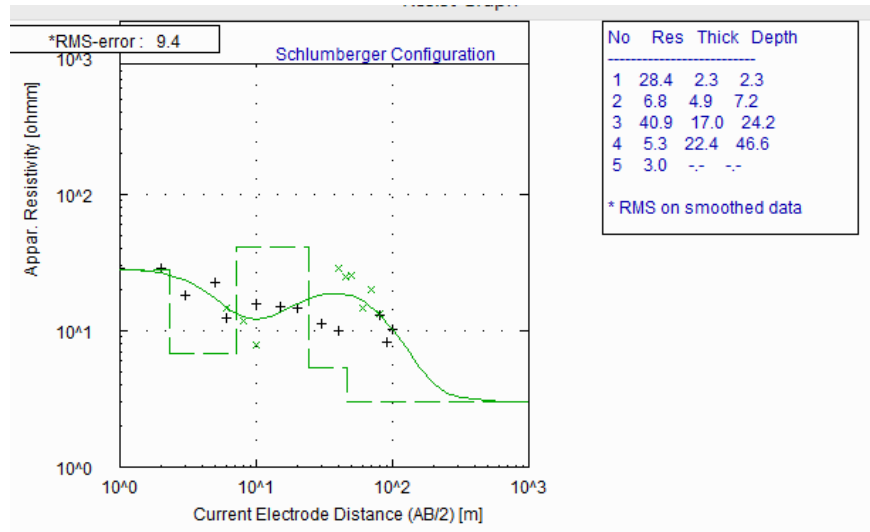

Fig. 9. VES 2 curve.

Fig. 7. Geological Map of the Study area. 
European Journal of Environment and Earth Sciences www.ej-geo.org

TABLE II: RANGES OF RESISTIVITY AND THE DEPTH OF THE LAYER OF THE SUBSURFACE LITHOLOGIC UNITS

\begin{tabular}{|c|c|c|c|c|}
\hline $\begin{array}{l}\text { No. Of } \\
\text { layers }\end{array}$ & $\begin{array}{c}\text { Resistivit } \\
\mathrm{y}(\Omega \mathrm{m})\end{array}$ & $\begin{array}{l}\text { Depth } \\
(\mathrm{m})\end{array}$ & Possible lithology & Remark \\
\hline 1. & 28.4 & 2.3 & $\begin{array}{c}\text { Top soil and/or } \\
\text { lateritic overburden }\end{array}$ & Vadose zone \\
\hline 2. & 6.8 & 7.2 & Weathered basement & Confining zone \\
\hline 3. & 40.9 & 24.2 & $\begin{array}{c}\text { Fairly weathered } \\
\text { basement }\end{array}$ & $\begin{array}{c}\text { Semi-permeable } \\
\text { layer }\end{array}$ \\
\hline 4. & 5.3 & 46.6 & $\begin{array}{c}\text { Fairly weathered } \\
\text { basement }\end{array}$ & Fracture zone \\
\hline 5. & 3.0 & & $\begin{array}{l}\text { Weathered-fresh } \\
\text { basement }\end{array}$ & Confining zone \\
\hline
\end{tabular}

Fig. 9 and Table II delineates the outcome of VES 2. The results indicate a five-layer earth with resistivity values starting from $2.3 \mathrm{~m}$ to $28.4 \Omega \mathrm{m}$. The topsoil is regarded as loosely incoherent sandy soil. Its thickness is $7.2 \mathrm{~m}$, and its resistivity is $6.8 \Omega \mathrm{m}$. What followed is the aquifer layer that has a thickness of $24.2 \mathrm{~m}$ and resistivity of $40.9 \Omega \mathrm{m}$ and is viewed to be coarse sand and held the aquifer. The thickness is high on this aquifer layer during this location is of and it is shallow giving that it's also located at just $40 \mathrm{~m}$ from the surface. The third layer during this location holds finemedium sand. Its value of resistivity is $5.3 \Omega \mathrm{m}$ and its thickness value is $20 \mathrm{~m}$. The fourth layer has value of resistivity of $46.6 \Omega \mathrm{m}$ and depth of $5.3 \mathrm{~m}$. Lastly, the fifth layer having depth to infinity and resistivity value of three. $3.0 \Omega \mathrm{m}$. The graph is showing an HQ type curve.
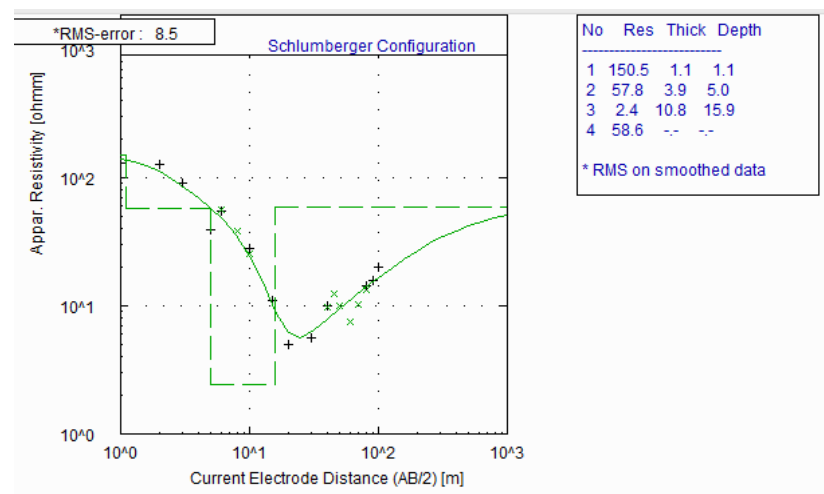

Fig. 10. VES 3 curve.

TABLE III: RESISTIVITY RANGES AND LAYER DEPTH OF SUBSURFACE LITHOLOGIC UNITS

\begin{tabular}{|c|c|c|c|c|}
\hline $\begin{array}{l}\text { No. of } \\
\text { layers }\end{array}$ & $\begin{array}{c}\text { Resistivity } \\
(\Omega \mathrm{m})\end{array}$ & $\begin{array}{c}\text { Depth } \\
(\mathrm{m})\end{array}$ & Possible lithology & Remark \\
\hline 1. & 150.5 & 1.1 & $\begin{array}{c}\text { Top soil and/or } \\
\text { lateritic overburden }\end{array}$ & Vadose zone \\
\hline 2. & 57.8 & 5.0 & Weathered basement & $\begin{array}{c}\text { Semi permeable } \\
\text { layer }\end{array}$ \\
\hline 3. & 2.4 & 15.0 & $\begin{array}{c}\text { Fractured weathered } \\
\text { basement }\end{array}$ & Fracture zone \\
\hline 4. & 58.6 & & $\begin{array}{c}\text { Weathered-fresh } \\
\text { basement }\end{array}$ & Confining zone \\
\hline
\end{tabular}

Result of VES 3 is presented in Fig. 10 and Table III. The result revealed a four-layer earth. The first layer is the topsoil with thickness and resistivity values of $1.1 \mathrm{~m}$ and $150.5 \Omega \mathrm{m}$, respectively. What composed the topsoil was the loosely non-amalgamated sandy soil. A weathered layer came next, and it has a thickness value of $5 \mathrm{~m}$ and resistivity value of $57.8 \Omega \mathrm{m}$ and it is composed of sandy soil. The third is the aquifer layer and is composed of coarse sand. Its thickness is $15 \mathrm{~m}$ and resistivity $2.4 \Omega \mathrm{m}$. The value of the resistivity of the fine-medium sand was $158.6 \Omega \mathrm{m}$ and the thickness was undefined; this was the fourth layer. Graph showing an $\mathrm{H}$ type curve.

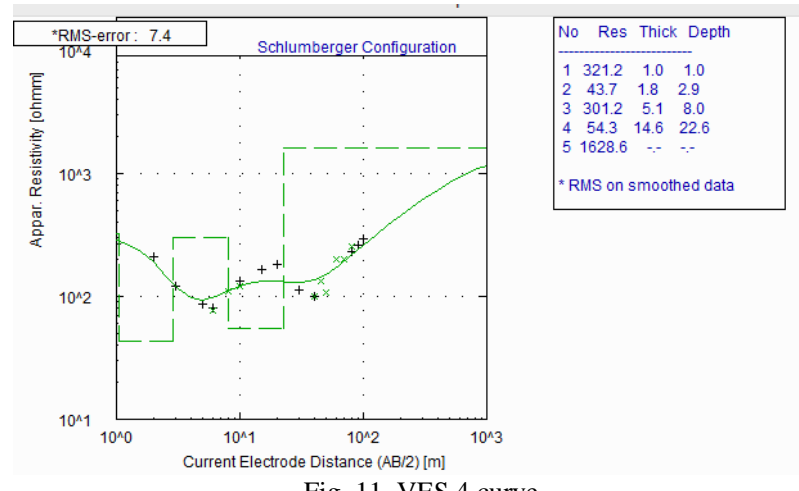

Fig. 11. VES 4 curve.

TABLE IV: RESISTIVITY RANGES AND LAYER DEPTH OF SUBSURFACE LITHOLOGICAL UNITS

\begin{tabular}{|c|c|c|c|c|}
\hline $\begin{array}{l}\text { No. of } \\
\text { layers }\end{array}$ & $\begin{array}{l}\text { Resistivity } \\
(\Omega \mathrm{m})\end{array}$ & $\begin{array}{l}\text { Depth } \\
\text { (m) }\end{array}$ & Possible lithology & Remark \\
\hline 1. & 321.1 & 1.0 & $\begin{array}{l}\text { Top soil and/or } \\
\text { lateritic overburden }\end{array}$ & Vadose zone \\
\hline 2. & 43.7 & 2.0 & $\begin{array}{l}\text { Weathered } \\
\text { basement }\end{array}$ & $\begin{array}{c}\text { Semi permeable } \\
\text { layer }\end{array}$ \\
\hline 3. & 54.3 & 8.0 & $\begin{array}{c}\text { Fairly weathered } \\
\text { basement }\end{array}$ & Fracture zone \\
\hline 4. & 1626.8 & & $\begin{array}{c}\text { Weathered-fresh } \\
\text { basement }\end{array}$ & Confining layer \\
\hline
\end{tabular}

Result of VES 4 is presented in Fig. 11 and Table IV. The results reveal a four-layer earth. The thickness of the first layer, which serves as the topsoil, is $1 \mathrm{~m}$ and its resistivity value was $321.1 \Omega \mathrm{m}$. The topsoil is composed of loosely non-solid sandy soil, which is succeeded by the weathered layer whose thickness is $2 \mathrm{~m}$ and resistivity is $43.7 \Omega \mathrm{m}$ and consists of sandy soil. The thickness of the third layer, which served as the aquifer layer, is $8.0 \mathrm{~m}$ and its resistivity value was $110.2 \Omega \mathrm{m}$. Coarse sandy soil makes up this layer. The last layer held fine-medium sand and has a resistivity value of $1626.8 \Omega \mathrm{m}$ its thickness is undefined. The graph shows an HA type curve.
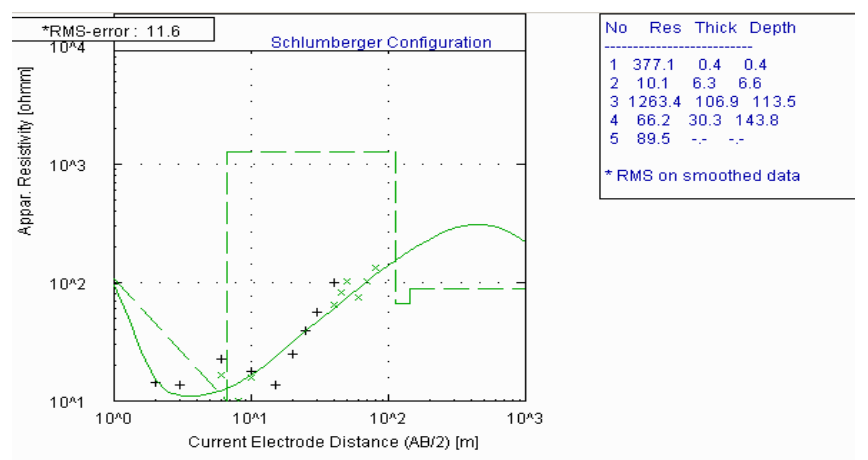

Fig. 12. VES 5 curve.

TABLE V: RESISTIVITY RANGES AND LAYER DEPTH OF SUBSURFACE LITHOLOGIC UNITS

\begin{tabular}{|c|c|c|c|c|}
\hline $\begin{array}{l}\text { No. of } \\
\text { layers }\end{array}$ & $\begin{array}{c}\text { Resistivity } \\
(\Omega \mathrm{m})\end{array}$ & $\begin{array}{l}\text { Depth } \\
\text { (m) }\end{array}$ & Possible lithology & Remark \\
\hline 1. & 377.1 & $0-4$ & $\begin{array}{c}\text { Top soil and/or } \\
\text { lateritic overburden }\end{array}$ & Vadose zone \\
\hline 2. & 10.1 & 0.6 & $\begin{array}{l}\text { Weathered } \\
\text { basement }\end{array}$ & $\begin{array}{c}\text { Semi permeable } \\
\text { layer }\end{array}$ \\
\hline 3. & 1263.6 & 113.5 & $\begin{array}{c}\text { Fairly weathered } \\
\text { basement }\end{array}$ & Fracture zone \\
\hline 4. & 66.2 & 143.8 & $\begin{array}{c}\text { Fairly weathered } \\
\text { basement }\end{array}$ & Confining zone \\
\hline 5. & 89.6 & & $\begin{array}{c}\text { Fresh weathered } \\
\text { basement }\end{array}$ & \\
\hline
\end{tabular}


Result of VES 5 is presented in Fig. 12 and Table V. The result revealed a five-layer earth. The thickness of the first layer, which served as the topsoil, is $8 \mathrm{~m}$ and has a resistivity value of $25.9 \Omega \mathrm{m}$. loosely unconsolidated soil makes it up. A weathered layer followed, and it had a thickness of $7 \mathrm{~m}$ and resistivity value of $15.6 \Omega \mathrm{m}$ and is composed of sandy soil. The thickness of the third layer, which served as the aquifer layer, is $30 \mathrm{~m}$ and has resistivity value of $78.4 \Omega \mathrm{m}$. This layer entails coarse sandy soil and held the aquifer. The resistivity value of the fourth layer, which served as a container for the fine-medium sand, is 117.2 $\Omega \mathrm{m}$ and its thickness is undefined. The graph shows an $\mathrm{H}$ curve.

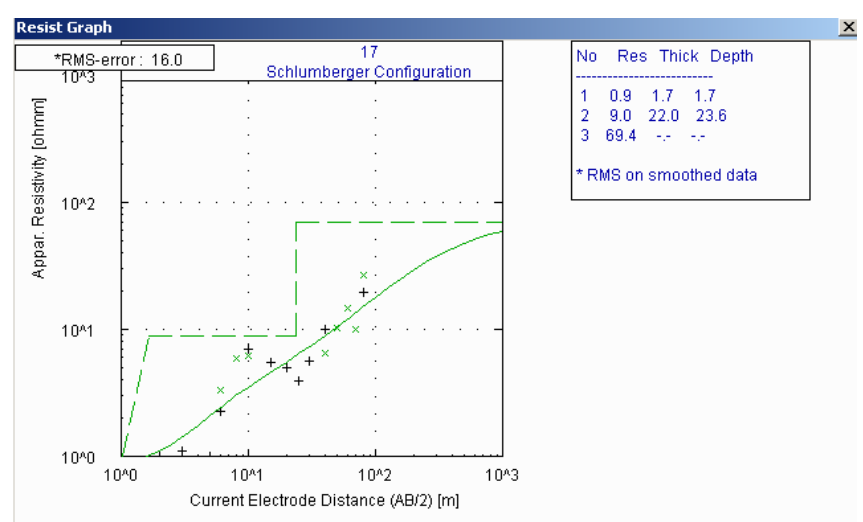

Fig. 13. VES 6 curve.

TABLE VI: RESISTIVITY RANGES AND LAYER DEPTH OF SUBSURFACE LITHOLOGIC UNITS

\begin{tabular}{ccccc}
\hline \hline $\begin{array}{c}\text { No. } \\
\text { Of } \\
\text { layers }\end{array}$ & $\begin{array}{c}\text { Resistivity } \\
(\Omega \mathrm{m})\end{array}$ & $\begin{array}{c}\text { Depth } \\
(\mathrm{m})\end{array}$ & Possible lithology & Remark \\
\hline 1. & 0.9 & 1.7 & $\begin{array}{c}\text { Top soil and/or } \\
\text { lateritic overburden } \\
\text { Weathered } \\
\text { basement }\end{array}$ & $\begin{array}{c}\text { Fadose zone } \\
\text { zone }\end{array}$ \\
2. & 9.0 & 23.6 & $\begin{array}{c}\text { Fairly/fracture } \\
\text { weathered } \\
\text { basement }\end{array}$ & $\begin{array}{c}\text { Confining } \\
\text { zone }\end{array}$ \\
3. & 69.4 & & & \\
\hline \hline
\end{tabular}

Result of VES 6 is presented in Fig. 13 and Table VI and it is made up of three-layer earth. Loosely unconsolidated sandy soil made up the topsoil, as shown by VES data at the location. The thickness of the topsoil is $1.7 \mathrm{~m}$ with resistivity value of $1.0 \Omega \mathrm{m}$. What followed is fairly or fractured weathered layer, which serves as the aquifer layer is constructed of coarse sandy soil has thickness of $23.6 \mathrm{~m}$ and its resistivity value is $9 \Omega \mathrm{m}$. Sandy soil composed the weathered layer. The third layer, which is the last layer is composed of coarse sandy soil. It has a resistivity value of $69.4 \Omega \mathrm{m}$ and its thickness is undefined. The graph shows an A curve.

TABLE VII: RESISTIVITY RANGES AND LAYER DEPTH OF SUBSURFACE LITHOLOGIC UNITS

\begin{tabular}{|c|c|c|c|c|}
\hline $\begin{array}{l}\text { No. of } \\
\text { layers }\end{array}$ & $\begin{array}{c}\text { Resistivity } \\
(\Omega \mathrm{m})\end{array}$ & $\begin{array}{c}\text { Depth } \\
(\mathrm{m})\end{array}$ & Possible lithology & Remark \\
\hline 1. & 1.6 & 3.4 & $\begin{array}{c}\text { Top soil and/or } \\
\text { lateritic overburden }\end{array}$ & Vadose zone \\
\hline 2. & 13.0 & 5.8 & $\begin{array}{c}\text { Fairly Weathered } \\
\text { basement }\end{array}$ & $\begin{array}{l}\text { Permeable } \\
\text { layer }\end{array}$ \\
\hline 3. & 209.1 & 11.8 & Fractured basement & $\begin{array}{c}\text { Confining } \\
\text { layer }\end{array}$ \\
\hline 4. & 2485.4 & & Fresh basement & \\
\hline
\end{tabular}

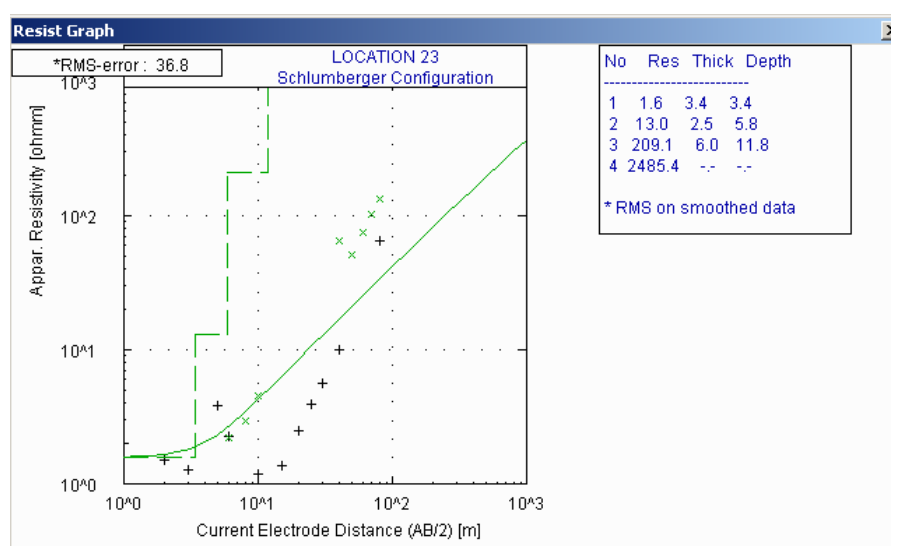

Fig. 14. VES 7 curve.

Results of VES presented in Fig. 14 and Table VII. The result indicates that loose unconsolidated sandy soil composed the topsoil. The thickness of the topsoil is $3.4 \mathrm{~m}$ and its resistivity value is $1.6 \Omega \mathrm{m}$. What followed is a fairly or fractured weathered layer, which served as the aquifer layer is composed of coarse sandy soil. Its thickness is $5.8 \mathrm{~m}$ and its value of resistivity is $13 \Omega \mathrm{m}$. Sandy soil composed the weathered layer. The resistivity of the third layer is $209.1 \Omega \mathrm{m}$ and its thickness is $11.8 \mathrm{~m}$. The fourth layer which is the last layer is made up of coarse sandy soil with resistivity value of $24 \Omega \mathrm{m}$ with undefined thickness. This shows an A curve.

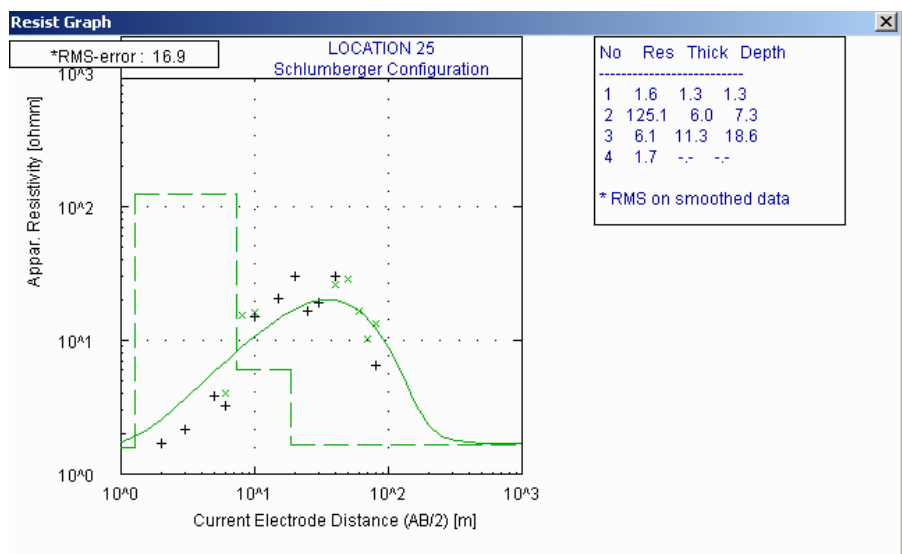

Fig. 15. VES 8 curve.

TABLE VIII: RESISTIVITY RANGES AND LAYER DEPTH OF SUBSURFACE LITHOLOGIC UNITS

\begin{tabular}{|c|c|c|c|c|}
\hline $\begin{array}{l}\text { No. of } \\
\text { layers }\end{array}$ & $\begin{array}{l}\text { Resistivity } \\
(\Omega \mathrm{m})\end{array}$ & $\begin{array}{l}\text { Depth } \\
(\mathrm{m})\end{array}$ & Possible lithology & Remark \\
\hline 1. & 1.6 & 1.3 & $\begin{array}{l}\text { Top soil and/or } \\
\text { lateritic overburden }\end{array}$ & Vadose zone \\
\hline 2. & 125.1 & 7.3 & $\begin{array}{l}\text { Weathered } \\
\text { basement }\end{array}$ & $\begin{array}{c}\text { Semi permeable } \\
\text { layer }\end{array}$ \\
\hline 3. & 6.1 & 18.6 & $\begin{array}{c}\text { Fairly weathered } \\
\text { basement }\end{array}$ & Fracture zone \\
\hline 4. & 1.7 & & $\begin{array}{c}\text { Fresh weathered } \\
\text { basement }\end{array}$ & Confining layer \\
\hline
\end{tabular}

Results of VES presented in Fig. 15 and Table IIIV. This shows that the earth is in four layers. The VES data at the location indicated that loose unconsolidated sandy soil composed the topsoil. The thickness of the topsoil is $1.3 \mathrm{~m}$, and its resistivity value is $1.6 \Omega \mathrm{m}$. What comes after is a weathered layer with a thickness of $7.3 \mathrm{~m}$ and its value of resistivity is $125.1 \Omega \mathrm{m}$ and is composed of sandy soil. The third layer follows, which serves as the aquifer layer and has a thickness of $18.6 \mathrm{~m}$ and its resistivity value is $6.1 \Omega \mathrm{m}$. 
This layer holds the aquifer in this location. The resistivity value of the fourth layer, which holds the fine-medium sand is $1.7 \Omega \mathrm{m}$ and its thickness is undefined. Curve type is $\mathrm{K}$.
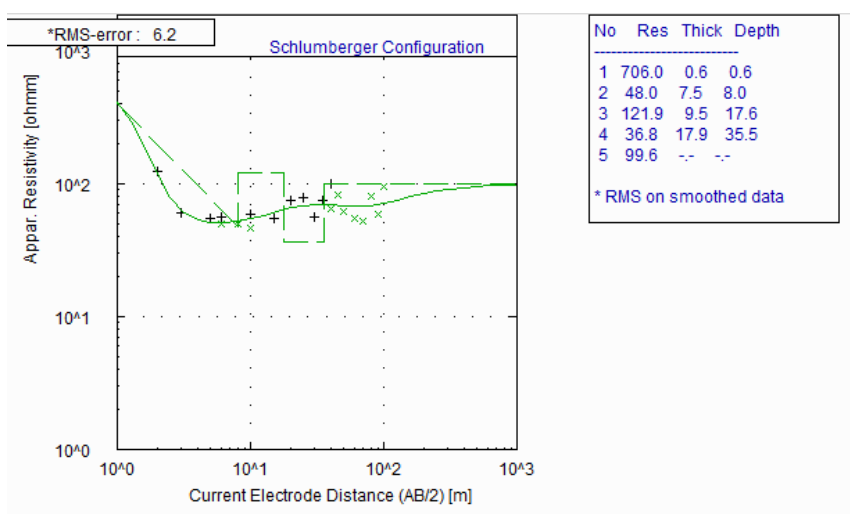

Fig. 16 VES 9 curve.

TABLE IX: RESISTIVITY RANGES AND LAYER DEPTH OF SUBSURFACE LITHOLOGIC UNITS

\begin{tabular}{|c|c|c|c|c|}
\hline $\begin{array}{l}\text { No. of } \\
\text { layers }\end{array}$ & $\begin{array}{c}\text { Resistivity } \\
(\Omega \mathrm{m})\end{array}$ & $\begin{array}{c}\text { Depth } \\
(\mathrm{m})\end{array}$ & Possible lithology & Remark \\
\hline 1. & 706.0 & 0.6 & $\begin{array}{c}\text { Top soil and/or } \\
\text { lateritic overburden }\end{array}$ & Vadose zone \\
\hline 2. & 48.0 & 8.0 & $\begin{array}{c}\text { Fairly Weathered } \\
\text { basement }\end{array}$ & Confining zone \\
\hline 3. & 121.9 & 17.6 & $\begin{array}{l}\text { Weathered } \\
\text { basement }\end{array}$ & $\begin{array}{c}\text { Semi permeable } \\
\text { layer }\end{array}$ \\
\hline 4. & 36.8 & 35.5 & $\begin{array}{c}\text { Weathered fractured } \\
\text { basement }\end{array}$ & $\begin{array}{c}\text { Zone of } \\
\text { possible aquifer }\end{array}$ \\
\hline 5. & 99.6 & & Fresh basement & Confining layer \\
\hline
\end{tabular}

Result of VES 9 is presented in Fig. 16 and Table IX. The results indicate that the subsurface is composed by fivelayer earth. The VES data at the location indicated that loose unconsolidated sandy soil composed the topsoil. The thickness of the topsoil is $0.6 \mathrm{~m}$, and its value of resistivity is $706 \Omega \mathrm{m}$. What succeeds it is a weathered layer that has a thickness of $8.0 \mathrm{~m}$ and a resistivity value of $48 \Omega \mathrm{m}$. it is composed of sandy soil. What followed is the third layer that has a thickness of $17.6 \mathrm{~m}$ and value of resistivity of $121.9 \Omega \mathrm{m}$. The weathered layer, which serves as the aquifer layer has a thickness of $35.5 \mathrm{~m}$ and value of resistivity of $36.8 \Omega \mathrm{m}$. This layer held the aquifer in this location. The fifth layer which held fine-medium sand and has a resistivity value of $99.6 \Omega \mathrm{m}$ and its thickness if undefined. The curve type is the HQ type curve.

\section{CONCLUSION}

Table X summarizes interpreted electrical resistivity survey. Nine (9) VES were conducted on nine (9) different locations across the mapped area. The geo-electric sections records VES location 6 and 7 to be of a three-layer sub surface, VES location 1,3,4 and 5 indicated that the section is qualified by mainly four geo-electric subsurface layers with the exception of VES location 2 and 9 which indicates a five-layer earth. VES locations 1, 3, 4 and 5 are characterized by HA curve types which falls to a minimum and then rises again indicating resistivity increase from layer to layer. They represent the presence of four geologic layers. The rising right branch usually matches to the aquifer. VES location 6 and 7 which is the only VES qualified by threelayer earth reveals A-type curve, which show gradient changes, and which majorly is known to be an ascending curve. VES locations 2 and 9 are identified by HQ curve types which show curves that rise to a minimum initially and then decrease progressively representing the presence of five geologic layers.

Investigations have been conducted to delineate Groundwater potential aquifers by using electrical resistivity survey. These VES readings have been used to identify weathered and fractured horizons in the study area, and all of these constitute the aquifer zones. This research has provided information on the depth to the groundwater and the thickness of the aquifer unit in the study area. The development of an effective water scheme for the area requires this information.

Based on all the findings made in the interpretation of the VES data, the thickness and resistivity of the aquifers at most of the VES stations indicates good potential for groundwater. Finally, the area of study has a high potential for groundwater development. For example, location 2,3,4,7 and 9 are productive aquifer for drilling of borehole, while location 1,5,6 and 8 are unproductive aquifers which doesn't show good potential for groundwater exploration. For the sake of safety, random dumping of waste products like solid and liquid elements is essentially to avoided in nearby boreholes area. This is to avoid waste contamination to the aquifer replenishment in the shallow aquifers which are ranges from $2 \mathrm{~m}$ to $45 \mathrm{~m}$.

TABLE X: SUMMARY OF THE WEATHERED BASEMENT AQUIFER AND ITS CHARACTERISTICS

\begin{tabular}{|c|c|c|c|c|c|c|}
\hline $\begin{array}{l}\text { Location } \\
\text { Name }\end{array}$ & GPS Cordinates & $\begin{array}{l}\text { Elevation } \\
\quad(\mathrm{m})\end{array}$ & $\begin{array}{c}\text { Layer } \\
\text { Resistivity }(\Omega \mathrm{m})\end{array}$ & $\begin{array}{l}\text { Depth to } \\
\text { Water } \\
\text { (m) }\end{array}$ & $\begin{array}{l}\text { Thickness of } \\
\text { Aquifer(m) }\end{array}$ & $\begin{array}{l}\text { Curve } \\
\text { type }\end{array}$ \\
\hline VES 1 & $\mathrm{~N}^{\circ} 7^{\circ} 48^{\prime} 04.8^{\prime \prime} \mathrm{N}^{\circ} 6^{\circ} 43^{\prime} 50.9^{\prime \prime}$ & 118 & $1.0-1410.7$ & $1.3-4.7$ & 7.03 & $\mathrm{H}$ \\
\hline VES2 & $\begin{array}{l}\mathrm{N} 07^{\circ} 48^{\prime} 16.5^{\prime \prime} \\
\mathrm{E}^{\circ} 6^{\circ} 43^{\prime} 45.5^{\prime \prime}\end{array}$ & 126 & $3.0-40.9$ & $2.3-22.4$ & 44.3 & HQ \\
\hline VES3 & $\begin{array}{l}\text { N07 } 48^{\prime} 23.7^{\prime \prime} \\
\text { E06 }^{\circ} 43^{\prime} 59.6^{\prime \prime}\end{array}$ & 108 & $2.4-150.5$ & $1.0-10.8$ & 14.8 & $\mathrm{H}$ \\
\hline $\begin{array}{c}\text { VES } \\
4\end{array}$ & $\begin{array}{l}\text { N07 } 47^{\prime} 28.2^{\prime \prime} \\
\text { E06 }^{\circ} 44^{\prime} 51.8^{\prime \prime}\end{array}$ & 80 & $43.7-1628.6$ & $1.0-14.6$ & 21.6 & HA \\
\hline $\begin{array}{c}\text { VES } \\
5\end{array}$ & $\begin{array}{l}\text { N07 } 47^{\circ} 19.5^{\prime \prime} \\
\text { E06 } 44^{\prime} 08.3^{\prime \prime}\end{array}$ & 62 & $10.1-1263.4$ & $0.4-30.3$ & 143.4 & $\mathrm{H}$ \\
\hline $\begin{array}{l}\text { VES } \\
6\end{array}$ & $\begin{array}{l}\text { N07 } 48^{\prime} 42.5^{\prime \prime} \\
\text { E06 }^{\circ} 44^{\prime} 44.0^{\prime \prime}\end{array}$ & 83.8 & $0.9-69.4$ & $1.7-22.0$ & 21.6 & A \\
\hline $\begin{array}{l}\text { VES } \\
7\end{array}$ & $\begin{array}{l}\text { N07 } 48^{\prime} 33.7^{\prime \prime} \\
\text { E06 }^{\circ} 44^{\prime} 22.6^{\prime \prime}\end{array}$ & 88.7 & $1.6-2485.4$ & $2.5-6.0$ & 7.5 & A \\
\hline VES 8 & $\begin{array}{l}\text { N07 } 49^{\prime} 03.4^{\prime \prime} \\
\text { E06 }^{\circ} 44^{\prime} 36.2^{\prime \prime}\end{array}$ & 146 & $1.3-11.3$ & $1.3-11.3$ & 17.3 & $\mathrm{~K}$ \\
\hline VES 9 & $\begin{array}{l}\text { N07 } 51^{\prime} 50.5^{\prime \prime} \\
\text { E06 }^{\circ} 41^{\prime} 01.1^{\prime \prime}\end{array}$ & 199.7 & $36.8-706.0$ & $0.6-17.9$ & 33.9 & HQ \\
\hline
\end{tabular}




\section{RECOMMENDATION}

Boreholes should be drilled at areas with moderate to high groundwater potential that shows low resistivity value from the VES data also with no major fractures within the area that will pose threat to groundwater.

Additional research is certainly required to obtain further understanding of the process involved through the VES readings. This avails relevant general information for future groundwater development as means of decreasing incessant failures in boreholes and also will be relevant to the development of an effective water scheme for the area.

\section{ACKNOWLEDGMENT}

The preferred spelling of the word "acknowledgment We acknowledged the Department of Geology, Federal University Lokoja, Kogi State, Nigeria for making availability of the Instruments, data and to Mr. Umar Ahmad Aminu (Megatrons) for his reviewable efforts this research. We also Acknowledge Ibrahim Taiwo Akeem for his sacrifices.

\section{CONFLICT OF INTEREST}

There is no conflict of interest by the authors to publicize.

\section{FUNDING}

No funding of any form was received for this research.

\section{REFERENCES}

[1] Macdonald A. M., Cobbing J and Davies J. Developing groundwater for rural water supply in Nigeria: a report of the May 2005 training course and summary of the groundwater issues in the eight focus states. British Geological Survey Commissioned Report, CR/05/219N, 2005, 1-32.

[2] Fadele SI, Sule PO, Dewu BBM. The Use of Vertical Electrical Sounding (VES) for Groundwater Exploration around Nigerian College of Aviation Technology (NCAT), Zaria, Kaduna State, Nigeria. Pacific Journal of Science and Technology, 2013;14: 549-555.

[3] Singh, C. L. Role of Surface Geophysical Methods for Groundwater Exploration in Hard Rock Areas. Proceedings of International Workshop on Rural Hydrology and Hydraulics in Fissured Basement Zones, 1984:59-68.

[4] Adeniji AE, Obiora DN, Omonona OV, Ayuba R. Geoelectrical evaluation of groundwater potentials of Bwari basement area, Central Nigeria. Int J PhysSci, 2013;8(25):1350-1361. https://doi. org/10.5897/IJPS2013.3951.

[5] Oladunjoye M, Jekayinfa S. Efcacy of hummel (modifed Schlumberger) arrays of vertical electrical sounding in groundwater exploration: case study of parts of Ibadan Metropolis, Southwestern Nigeria. J Geophys, 2015.https://doi.org/10.1155/2015/612303.

[6] Olorunfemi M. O., \& Fasuyi S. A. Aquifer types and the geoelectric/hydrogeologic characteristic of part of the central basement terrain of Nigeria. Journal of Africa Earth Science, 1993;16(3), 309317. http://dx.doi.org/10.1016/0899-5362(93)90051-Q.

[7] Obianwu VI, Atan OE, Okiwelu AA. Determination of aquifer position using electric geophysical method. ApplPhys Res, 2015;7(2):83-92.

[8] Geobez Resources Ltd. Geophysical investigation for groundwater within the premises of Directorate of Rural Development, Lokoja, Kogi State. Unpublished Report for Kogi State Government, 2007.

[9] Falconer J.D. The geology and geography of Northern Nigeria. MacMillan, London, UK, 1911.

[10] Musa and Schoeneich. Estimate of Groundwater Resources, water demand and water supply to Lokoja Metropolis, Kogi State, central Nigeria. Journal of environmental social science, 2011;22(2):68-7.
[11] Sixtus N, Rasaq B, Ayomide O. Balogun. Evaluation of groundwater potentials of Orogun, South-South part of Nigeria using electrical resistivity method,r Applied Water Science, 2019;9:184.

[12] Burke KC, Dewey JF. Orogeny in Africa. In: Dessauvagie TFJ, Whiteman AJ (eds), Africa geology. University of Ibadan Press, Ibadan, 1972:583-608.

[13] Abaa SI. The structure and petrography of alkaline rocks of the Mada Younger Granite Complex, Nigeria. J Afr Earth Sci, 1983;3:107-113.

[14] Gandu AH, Ojo SB, Ajakaiye DE. A gravity study of the Precambrian rocks in the Malumfashi area of Kaduna State, Nigeria. Tectonophysics, 1986;126:181-194.

[15] Rahaman MA. Recent advances in the study of the basement complex of Nigeria. In: Geological Survey of Nigeria (ed) Precambrian Geol Nigeria, 1988:11-43.

[16] Dada SS. Proterozoic evolution of Nigeria. In: Oshi O (ed) The basement complex of Nigeria and its mineral resources (A Tribute to Prof. M. A. O. Rahaman). Akin Jinad \& Co. Ibadan, 2006:29-44.

[17] Rahaman, M.A. and Ocan, O. On Relationship in the Precambrian Migmatite-Gneiss of Nigeria. Journal of Mining and Geology, 1978;15, 23-30.

[18] Rahaman MA, Lancelot JR. Continental crust evolution in SWNigeria: constraints from $\mathrm{U} / \mathrm{Pb}$ dating of pre-Pan-African gneisses. In: Rapport d'activite 1980-1984 - Documents et Travaux du Centre Geologique et Geophysique de Montpellier 1984;4: 41.

[19] Tubosun IA. Geochronologie U/Pb du Socle Precambrian du Nigeria. Unpublished 3 eme Cycle Thesis, Univ. des Sciences et Techniques du Languedoc. Montpellier, 1983.

[20] Obaje NG. Fairways and reservoir potential of Pliocene - Recent sands in the shallow offshore Niger Delta. J Mining Geol, 2005;40:25-38.

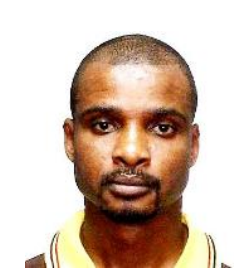

\section{Mu'awiya Baba Aminu}

Date of Birth : $1^{\text {st }}$ October 1982.

Place of Birth: Bauchi, Bauchi State, Nigeria.

MSc. In Prospection and Exploration for Oil and Gas Fields at Instituto Superior Minero Metalurgico de Moa, (University of Moa) Holguin Cuba, 2012.

BEng. Bachelor in Geological Engineering Instituto Superior Minero Metalurgico de Moa, (University of Moa) Holguin Cuba, 2011.

LECTURES in the Department of Geology, Federal University Lokoja, Kogi State, Nigeria.

Membership of Professional body: Society of Cuban Geology (SCG), Cuba. 